\title{
Efek xenia dan metaxenia pada persilangan tomat ranti dan tomat cherry
}

\author{
(Xenia and metaxenia effect on ranti tomato and cherry tomato cross pollination) \\ N. I. Widyasmara, F. Kusmiyati, dan Karno \\ Agroecotechnology, Department of Agriculture, Faculty of Animal and Agricultural Sciences, \\ Diponegoro University \\ Tembalang Campus, Semarang 50275 - Indonesia \\ CorrespondingE-mail:natwidyasmara@gmail.com
}

\begin{abstract}
Cherry tomato have various colour, shape and nutritious fruit. The aim of this research was to make population for genetic selection and to know about xenia and metaxenia effect on tomato crossing. The crossing was assigned in dialel crossing combination with Ranti tomato, Cherry tomato var. Grape, Red Pear and Indigo Rose as a crossing parents. The crossing combination was Ranti $x$ Grape, Ranti x Red Pear, Ranti x Indigo Rose, Grape x Ranti, Grape x Red Pear, Grape x Indigo Rose, Indigo Rose x Grape, Indigo Rose x Ranti, Indigo Rose x Red Pear. Parameter measured were crossing ability, fruit set ability, fruit ripening age, seed number and fruit shape. The result showed that Grape $x$ Red Pear crossing combination had the highest crossing ability and Indigo Rose $\mathrm{x}$ Red Pear had the highest fruit set ability. Xenia and metaxenia effects were showed in fruit ripening age, seed number and fruit shape. Genotype of Red Pear x Indigo Rose was found as superior genotype candidate for ripening age, seed number and had highest percentage of fruit shape alteration.
\end{abstract}

Keywords : Hybridization, xenia, metaxenia, tomato, cherry tomato.

\begin{abstract}
ABSTRAK
Tomat cherry mempunyai beragam warna, bentuk, serta memiliki nilai gizi yang tinggi. Tujuan penelitian ini adalah menciptakan populasi awal untuk seleksi, serta mengetahui efek xenia dan metaxenia terhadap hasil persilangan. Persilangan dilakukan menggunakan kombinasi persilangan dialel lengkap dengan tetua tomat Ranti, tomat cherry kultivar Grape, Red Pear dan Indigo Rose. Kombinasi persilangan adalah Ranti x Grape, Ranti x Red Pear, Ranti x Indigo Rose, Grape x Ranti, Grape x Red Pear, Grape x Indigo Rose, Indigo Rose x Grape, Indigo Rose x Ranti, Indigo Rose x Red Pear. Parameter yang diamati adalah keberhasilan persilangan, keberhasilan pembentukan buah, umur panen, jumlah biji dan bentuk buah secara membujur. Hasil penelitian menunjukan keberhasilan persilangan tertinggi adalah kombinasi persilangan Grape $\mathrm{x}$ Red Pear dan keberhasilan pembentukan buah tertinggi adalah kombinasi persilangan Indigo Rose x Red Pear. Efek xenia dan metaxenia pada persilangan tomat dapat diamati pada karakter umur panen, jumlah biji dan bentuk buah. Genotipe persilangan Red Pear x Indigo Rose merupakan kandidat genotipe unggul pada karakter umur panen, jumlah biji dan memiliki persentase perubahan bentuk buah membujur tertinggi.
\end{abstract}

Kata kunci : Hibridisasi, xenia, metaxenia, tomat, tomat cherry.

\section{PENDAHULUAN}

Tomat (Lycopersicum esculentum Mill) merupakan komoditas hortikultura yang bernilai ekonomis tinggi. Munculnya gaya hidup sehat berperan meningkatkan tingkat kebutuhan masyarakat akan buah tomat. Tren minat konsumsi masyarakat Internasional bergeser kepada tipe buah yang kecil, memiliki warna yang menarik, rasa manis dan memiliki nilai gizi yang tinggi. Tren yang terbentuk mempengaruhi peningkatan permintaan pasar terhadap kebutuhan 
tomat cherry.

Tomat cherry (Lycopersicum esculentum var. cerasiforme) banyak digunakan sebagai buah langsung konsumsi serta memiliki nilai gizi yang tinggi, mengandung antioksidan dan memiliki rasa yang enak (Kavitha et al. 2014). Tomat cherry memiliki kandungan bahan kering dan padatan terlarut lebih tinggi dibanding tomat sayur. Tomat cherry memiliki kandungan gula fruktosa dan glukosa serta asam organik yang tinggi (Renuka et al. 2014). Varietas introduksi seperti varietas Grape, Red Pear dan Indigo Rose memiliki beberapa kekurangan, seperti kurang adaptif pada kondisi lingkungan di Indonesia. Tomat Ranti (Lycopersicum esculentum var. commune Bailey) merupakan tomat lokal yang banyak dibudidayakan oleh petani, sehingga memiliki daya daptasi lebih tinggi.

Persilangan merupakan upaya meningkatkan keragaman genetik tanaman. Hibridisasi merupakan upaya manipulasi dengan menggabungkan dua sifat atau lebih tanaman untuk menghasilkan individu baru (Setiamiharja, 1993). Tujuan persilangan buatan adalah menggabungkan karakter baik ke dalam satu genotipe baru, memperluas keragaman genetik, memanfaatkan vigor hibrida dan menguji potensi tetua (Syukur et al., 2015). Keragaman genetik yang dihasilkan oleh segregasi gen tetua dapat digunakan sebagai sumber seleksi tanaman. Pengamatan hasil persilangan diasumsikan baru dapat diekspresikan pada generasi berikutnya.

Xenia merupakan pengaruh polen terhadap penampilan buah dan biji hasil persilangan pada jaringan tetua betina asal persilangan. Xenia dapat diamati pada organ tetua betina (buah) saat masih berbentuk embrio dan endosperma (Bullant dan Gallais, 1998). Metaxenia merupakan efek polen terhadap perkembangan jaringan buah tetua betina diluar embrio dan endosperma yang disebabkan oleh hormon yang dihasilkan setelah peristiwa pembuahan ganda (Liu, 2008). Metaxenia dapat diamati pada jaringan buah tetua betina asal, seperti pericarp dan jaringan diluar embrio dan endosperma (Denney, 1992). Metaxenia dapat digunakan untuk mengidentifikasi tetua jantan yang baik dalam upaya mempercepat pematangan buah (Olfati et al., 2010). Efek polen dibagi menjadi efek individu polen dan efek interaksi polen dan tetua. Efek individual polen merupakan efek langsung polen terhadap tetua betina yang dapat diobservasi hanya setelah persilangan pada F0, sedangkan efek interaksi polen dan tetua dapat diamati pada generasi $\mathrm{F} 1$ persilangan (Kahriman et al., 2017).

Penelitian ini bertujuan untuk mengetahui efek xenia dan metaxenia pada persilangan tomat ranti dan tomat cherry sebagai upaya deteksi keragaman secara dini.

\section{MATERI DAN METODE}

Penelitian telah dilaksanakan pada bulan Desember 2016 - Juli 2017 di Rumah Kaca Cv. Taburmas, Bandungan, Kabupaten Semarang, Jawa Tengah serta Laboratorium Fisiologi dan Pemuliaan Tanaman, Fakultas Peternakan dan Pertanian, Universitas Diponegoro, Semarang.

\section{Materi}

Bahan yang digunakan dalam penelitian ini adalah benih tomat Ranti (Lycopersicon esculentum var commune), benih tomat cherry (Lycopersicon esculentum var. cerasiforme) varietas Grape, Red Pear dan Indigo Rose yang berasal dari benih bersari bebas perusahaan Mr. Forthergils, Ohio Heirloom Seed dan PT. Benih Citra Asia, media tanam. Alat yang digunakan dalam penelitian adalah tray semai, polibag, pinset, sedotan, plastik, benang, Union for the Protection of New Varieties of Plant (UPOV) tomato guidelines, buret, gelas ukur, hand refractometer.

\section{Metode}

Penelitian ini dilakukan menggunakan metode dialel II penuh menurut Griffing (1956). Tetua tomat yang digunakan tomat Ranti, tomat cherry varietas Grape, Red Pear dan Indigo Rose. Kombinasi persilangan berjumlah 16 persilangan yang terdiri dari 4 tangkar dalam dan 12 kombinasi persilangan. Kombinasi persilangan berupa Ranti x Grape, Ranti x Red Pear, Ranti x Indigo Rose, Grape x Ranti, Grape x Red Pear, Grape $x$ Indigo Rose, Red Pear x Grape, Red Pear $x$ Ranti, Red Pear x Indigo Rose, Indigo Rose x Grape, Indigo Rose $x$ Ranti dan Indigo Rose $x$ Red Pear. Setiap tetua ditanam sebanyak 32 tanaman didalam polybag dengan jarak tanam 50 $\mathrm{x} 60 \mathrm{~cm}$. 
Tanaman tomat disemai pada tray semai sampai umur 30 hari. Tanaman dipindahkan ke polibag berukuran $30 \mathrm{~cm}$ pada umur 30 hari. Tanaman ditanam pada Rumah Kaca hingga siap disilangkan.

Persilangan pada tanaman tomat dilakukan pada pada usia tanam ke-43 hingga 65. Waktu persilangan adalah pagi hari pukul 07.00-10.00 WIB. Persilangan dilakukan dengan melakukan kastrasi pada bunga tetua betina yang belum mekar dengan membuang mahkota dan tangkai sari bunga tomat cherry. Tetua jantan dipilih dari bunga yang telah mekar segar. Polen dari tetua yang telah ditentukan diambil menggunakan pinset dan dioleskan ke kepala putik bunga betina. Bunga betina yang telah dilakukan polinasi ditutup menggunakan sedotan dan diberi label pengenal.

Panen pada umur 40-60 hari setelah polinasi pada buah yang telah masak secara fisiologis dengan memotong pangkal buah. Buah tomat cherry yang sudah dipanen dilakukan analisis data sesuai parameter penelitian. Buah tomat cherry yang telah dianalisis dilakukan ekstraksi benih tomat dengan mencuci menggunakan $\mathrm{HCl} 2 \%$ hingga pulp hilang pengeringan benih tomat cherry secara manual menggunakan sinar matahari selama 10-15 hari untuk disimpan benihnya.

\section{Analisis data}

Pengamatan tanaman dilakukan secara individu pada masing-masing hasil kombinasi persilangan. Parameter kuantitatif yang diamati adalah persentase keberhasilan persilangan, persentase keberhasilan pembentukan buah, umur panen dan jumlah biji. Perhitungan keberhasilan persilangan pada hari ke-3 setelah persilangan dengan rumus :

Keberhasilan Persilangan (\%)

$$
=\frac{\sum \text { persilangan yang berhasil }}{\sum \text { seluruh persilangan }} \times 100
$$

Perhitungan keberhasilan pembentukan buah pada hari ke-7 setelah persilangan dengan rumus :

Keberhasilan pembentukan buah (\%) $=\frac{\sum \text { buah yang terbentuk pada hari ke- } 7}{\sum \text { bakal buah terbentuk pada hari ke }-3} \times 100$
Data kuantitatif umur panen dan jumlah biji dianalisis menggunakan menggunakan uji-T independent pada taraf $5 \%$.

Data kualitatif meliputi bentuk buah secara membujur. Data kualitatif dianalisis berdasarkan (UPOV) tomato guidelines (2013). Perhitungan bentuk buah yang berubah dibanding tangkar dalam tetua betina persilangan dilakukan dengan menghitung persentase bentuk buah yang berubah dengan rumus:

$$
\begin{aligned}
& \text { Bentuk buah yang berubah (\%) } \\
& \quad=100 \%-\left(\frac{\sum \text { bentuk buah selfing }}{\sum \text { bentuk buah lain }} \times 100 \%\right)
\end{aligned}
$$

\section{HASIL DAN PEMBAHASAN}

\section{Keberhasilan Persilangan dan Keberhasilan Pembentukan Buah}

Data hasil keberhasilan persilangan dan pembentukan buah tangkar dalam dan kombinasi persilangan disajikan pada Tabel 1 .

Persentase keberhasilan persilangan tertinggi dihasilkan oleh kombinasi persilangan Grape $\mathrm{x}$ Red Pear sebesar 96,97\%. Keberhasilan persilangan terendah dihasilkan oleh kombinasi persilangan Ranti x Red Pear sebesar 40\%. Persentase keberhasilan pembentukan buah disajikan pada Tabel 1. Tomat Ranti x Red Pear dan Ranti $x$ Indigo Rose memiliki persentase keberhasilan persilangan yang rendah. Faktor yang mempengaruhi keberhasilan persilangan diantaranya kondisi polen tetua jantan dan tingkat kompabilitas persilangan. Keberhasilan persilangan dipengaruhi oleh self incompability, intensitas polinasi serta cuaca saat polinasi (Yunita et al., 2015). Keberhasilan persilangan merupakan indikator dalam menentukan kompabilitas antara tetua persilangan. Ambarwati et al. (2009) menyatakan bahwa terdapat kecenderungan bunga yang disilangkan akan gugur dan tidak dapat membentuk buah. Keberhasilan pembentukan buah tertinggi adalah kombinasi persilangan Indigo Rose x Red Pear sebesar 92,31\% dan keberhasilan pembentukan buah terendah adalah kombiansi persilangan Ranti x Grape dan Ranti x Red Pear sebesar 0\%. Kegagalan pembentukan buah pada persilangan tangkar dalam dan kombinasi persilangan dapat menyebabkan bakal buah rontok dan tidak berkembangnya bakal buah. 
Tabel 1. Keberhasilan persilangan dan pembentukan buah

\begin{tabular}{cccc}
\hline \hline Kombinasi persilangan & $\begin{array}{c}\text { Jumlah bunga } \\
\text { disilangkan }\end{array}$ & $\begin{array}{c}\text { Keberhasilan } \\
\text { Persilangan }\end{array}$ & $\begin{array}{c}\text { Keberhasilan } \\
\text { Pembentukan Buah }\end{array}$ \\
\hline Ranti x Grape & 40 & 82,50 & 0,00 \\
Ranti x Red Pear & 5 & 40,00 & 0,00 \\
Ranti x Indigo Rose & 17 & 52,94 & 22,22 \\
Grape x Ranti & 40 & 92,50 & 51,35 \\
Grape x Red Pear & 33 & 96,97 & 56,25 \\
Grape x Indigo Rose & 35 & 77,15 & 66,67 \\
Red Pear x Grape & 9 & 88,89 & 87,50 \\
Red Pear x Ranti & 21 & 61,90 & 30,76 \\
Red Pear x Indigo Rose & 10 & 70,00 & 42,85 \\
Indigo Rose x Grape & 16 & 68,75 & 62,90 \\
Indigo Rose x Ranti & 29 & 82,75 & 92,31 \\
Indigo Rose x Red Pear & 14 & 92,86 & 76,47 \\
Tangkar dalam Grape & 35 & 97,14 & 35,48 \\
Tangkar dalam Ranti & 35 & 88,57 & 66,67 \\
Tangkar Dalam Red Pear & 25 & 72,00 & 73,91 \\
Tangkar Dalam Indigo Rose & 35 & 92,00 & \\
\hline
\end{tabular}

Buah yang rontok dan tidak berkembang dapat disebabkan oleh faktor fisiologis tanaman maupun faktor lingkungan. Menurut Darjanto dan Satifah (1990) embrio dan endosperm pada bakal biji hasil polinasi dapat berhenti tumbuh karena kombinasi persilangan yang inkompatibel, dan mengakibatkan bakal buah yang terbentuk tidak berkembang mapun gugur sebelum matang. Hazra et al. (2007) menyatakan suhu lingkungan yang tinggi pada budidaya tomat dapat menyebabkan kegagalan pembentukan buah, pertumbuhan bunga abnormal, rendahnya pertumbuhan serbuk sari, intensitas bunga rendah, gugurnya ovul dan berkurangnya kandungan karbohidrat buah. Frimpong (2014) menyatakan persilangan pada musim hujan memiliki rasio keberhasilan polinasi stabil $95 \%$ dan pada musim kemarau turun menjadi $0 \%$.

Tomat Ranti sebagai tetua betina menunjukan inkompabilitas persilangan dengan tomat cherry varietas Grape, Red Pear dan Indigo Rose.

Inkompabilitas persilangan salah satunya disebabkan oleh jarak genetik tetua persilangan. Poespodarsono (1986) menyatakan bahwa inkompabilitas atau ketidak serasian silang salah satunya dapat disebabkan oleh faktor genetik seperti tingkat kekerabatan. Tomat Ranti (Lycopersicum esculentum var. commune) memiliki tingkat kekerabatan yang cukup dekat dengan Tomat Cherry (Lycopersicum esculentum var cerasiforme) yang berada dalam satu spesies, sehingga memiliki kemungkinan terjadi inkompabilitas genetik.

\section{Karakter Kuantitatif}

Hasil persilangan dan tangkar dalam pada parameter umur panen dan jumlah biji disajikan pada Tabel 2.

Kombinasi persilangan yang memberikan umur panen paling rendah adalah persilangan Grape x Red Pear sebesar 51,60 hari. Kombinasi persilangan yang memberikan umur panen paling tinggi adalah persilangan Ranti x Indigo Rose. Hasil kombinasi persilangan Ranti $x$ Indigo Rose berpengaruh nyata terhadap penambahan umur panen. Kombinasi persilangan Grape x Ranti, Grape x Red Pear, Grape x Indigo Rose dapat mempercepat umur panen buah dibanding tangkar dalam tomat Grape. Kombinasi Red Pear x Grape, Red Pear x Ranti, Red Pear x Indigo Rose dapat mempercepat umur panen buah dibanding tangkar dalam Red Pear. Persilangan Indigo Rose x Ranti 
Tabel 2. Karakter umur panen dan jumlah biji hasil kombinasi silang dan tangkar dalam

\begin{tabular}{|c|c|c|c|}
\hline Tangkar dalam & Kombinasi persilangan & $\begin{array}{l}\text { Umur Panen } \\
\text {-----(hari)----- }\end{array}$ & Jumlah biji \\
\hline \multirow[t]{2}{*}{ Ranti } & & $46,00 \pm 0,58$ & $58,00 \pm 5,13$ \\
\hline & Ranti xIndigo Rose & $60,00 *$ & $52,00 \pm 0,00^{\mathrm{ns}}$ \\
\hline \multirow[t]{4}{*}{ Grape } & & $59,00 \pm 0,00$ & $51,00 \pm 8,54$ \\
\hline & Grape x Ranti & $53,20 \pm 1,51^{*}$ & $19,13 \pm 4,11 *$ \\
\hline & Grape x Red Pear & $51,60 \pm 1,81^{*}$ & $25,13 \pm 3,68^{*}$ \\
\hline & Grape $\mathrm{x}$ Indigo Rose & $51,88 \pm 1,68^{*}$ & $39,98 \pm 4,73^{\mathrm{ns}}$ \\
\hline \multirow[t]{4}{*}{ Red Pear } & & $59,00 \pm 0,00$ & $71,00 \pm 4,16$ \\
\hline & Red Pear x Grape & $54,29 \pm 1,60^{*}$ & $31,43 \pm 6,89^{*}$ \\
\hline & Red Pear x Ranti & $56,86 \pm 2,87^{*}$ & $26,80 \pm 8,11 *$ \\
\hline & Red Pear x Indigo Rose & $51,67 \pm 1,67^{*}$ & $17,87 \pm 3,18^{*}$ \\
\hline \multirow[t]{4}{*}{ Indigo Rose } & & $56,33 \pm 1,45$ & $73,67 \pm 2,03$ \\
\hline & Indigo Rose x Grape & $56,90 \pm 7,70^{*}$ & $58,22 \pm 8,95^{\mathrm{ns}}$ \\
\hline & Indigo Rose $\mathrm{x}$ Ranti & $55,40 \pm 0,76^{\mathrm{ns}}$ & $27,60 \pm 7,46^{*}$ \\
\hline & Indigo Rose x Red Pear & $57,07 \pm 1,16^{\mathrm{ns}}$ & $43,77 \pm 7,23^{*}$ \\
\hline
\end{tabular}

Keterangan : notasi * berbeda nyata, ns menyatakan tidak signifikan pada taraf $5 \%$ berdasarkan uji $\mathrm{T}$ independen dibanding dengan tangkar dalam tetua betina persilangan.

terbukti dapat mempercepat umur panen buah tomat dibanding tangkar dalam Indigo Rose. Efek penggunaan polen yang berbeda terbukti menimbulkan keragaman antara hasil kombinasi persilangan dibanding tangkar dalam tetua betina persilangan pada parameter umur panen buah. Hal ini membuktikan terdapat efek metaxenia terhadap hasil persilangan. Penelitian sebelumnya menyebutkan persilangan buatan dapat mempercepat umur panen kedelai pada persilangan Burangrang dan Gepak kuning (Setyaningsih, 2011), persilangan buah naga Hylocereus polyrhizus dan Hylocereus undatus menyebabkan umur panen buah menjadi lebih cepat dibanding kontrol (Aini, 2008). Penelitian Olfati et al. (2010) menyatakan bahwa pengaruh metaxenia dapat digunakan untuk mengidentifikasi tetua jantan yang baik dalam upaya mempercepat periode perkembangan atau pematangan buah.

Data hasil pengamatan jumlah biji masing masing kombinasi perlakuan disajikan pada Tabel 2. Kombinasi persilangan yang memiliki rerata jumlah biji terendah adalah kombinasi persilangan Grape x Ranti sebesar 19,13. Persilangan yang menghasilkan jumlah biji paling tinggi adalah Indigo Rose x Grape sebanyak 58,22. Persilangan
Ranti x Indigo Rose tidak berpengaruh nyata menurunkan jumlah biji tangkar dalam tetua Ranti. Persilangan Grape x Ranti dan Grape Red Pear berpengaruh nyata menurunkan jumlah biji dibanding tangkar dalam tetua Grape. Kombinasi persilangan Red Pear x Grape, Red Pear x Ranti dan Red Pear $x$ Indigo Rose berpengaruh nyata dalam menurunkan jumlah biji dibanding tangkar dalam tetua Red Pear pada parameter jumlah biji. Persilangan Indigo Rose $x$ Ranti dan Indigo Rose $\mathrm{x}$ Red Pear pengaruh nyata dalam menurunkan jumlah biji dibandingkan tangkar dalam tetua Indigo Rose. Persilangan Grape x Indigo Rose dan Indigo Rose x Grape tidak memberikan pengaruh nyata dibanding tangkar dalam tetua Grape pada parameter jumlah biji.

Berdasarkan hasil persilangan, disimpulkan bahwa kombinasi persilangan mampu menurunkan jumlah biji dibandingkan dengan jumlah biji tetua betina hasil persilangan tangkar dalam. Penurunan jumlah biji juga dapat disebabkan oleh rendahnya jumlah ovul yang berhasil diserbuki oleh polen serta tingkat kompabilitas persilangan yang rendah. Penelitian oleh Piotto et al. (2013) menemukan bahwa persilangan tomat varietas Ruby Pusa dengan tomat Solanum galapagense mampu menurunkan 
jumlah biji tomat yang terbentuk. Karakter kuantitatif jumlah biji dikendalikan oleh banyak gen, sehingga karakter ini dipengaruhi oleh kondisi lingkungan (Syukur, 2015). Gardner (2008) menyatakan terdapat pengaruh jumlah asimilat yang dihasilkan tanaman terhadap jumlah biji masak fisiologis. Perbedaan jumlah benih bernas disebabkan oleh faktor genetik dan lingkungan (Sa'diyah et al., 2012).

\section{Parameter Kualitatif Bentuk Buah Membujur}

Keragaan buah tomat hasil tangkar dalam tetua betina persilangan serta kombinasi persilangan disajikan pada Ilustrasi 1, Ilustrasi 2, Ilustrasi 3 dan Ilustrasi 4.

Berdasarkan Ilustrasi 1, Ilustrasi 2, Ilustrasi 3 dan Ilustrasi 4 dapat dilihat bahwa terdapat perbedaan pada hasil kombinasi persilangan dan hasil tangkar dalam tetua betina. Tangkar dalam tomat Ranti memiliki bentuk buah Flattened, tangkar dalam tomat Grape memiliki bentuk buah circular, tangkar dalam tomat Red Pear memiliki bentuk buah Pyriform dan tangkar dalam tomat Indigo Rose memiliki bentuk buah oblate. Perubahan bentuk buah dipengaruhi oleh adanya segregasi gen akibat adanya persilangan. Berdasarkan pengamatan, sebagian besar hasil perlakuan kombinasi persilangan memiliki karakter bentuk buah secara membujur yang berbeda dengan persilangan tangkar dalam tetua betina. Menurut Zipori et al. (2007) menyatakan bahwa persilangan dengan tetua yang berbeda dapat meningkatkan keragaman genetik yang luas. Menurut Syukur et al. (2015), pemilihan tetua dalam program pemuliaan harus didasarkan pada keragaman genetik yang lebar agar dapat menghimpun alel yang berbeda.

Kombinasi persilangan yang memberikan perubahan penampilan bentuk buah membujur paling tinggi adalah persilangan Red Pear $\mathrm{x}$ Indigo Rose (Tabel 3). Kombinasi persilangan yang tidak memberikan perubahan bentuk buah secara membujur adalah kombinasi persilangan Ranti $\mathrm{x}$ Indigo Rose. Kombinasi persilangan yang berhasil memberikan pengaruh pada parameter bentuk buah membujur dibandingkan dengan hasil tangkar dalam tetua betina persilangan adalah persilangan Grape x Ranti, Grape x x Red Pear, Grape $x$ Indigo Rose, Red Pear $x$ Grape, Red Pear $x$ ranti, Red Pear $x$ Indigo Rose, Indigo Rose $x$ Grape, Indigo Rose $x$ Ranti dan Indigo Rose $x$ Red Pear. Pengaruh kombinasi persilangan disebabkan oleh penggunaan sumber polen yang berbeda.

Tabel 3. Bentuk buah secara membujur hasil kombinasi silang

\begin{tabular}{cllc}
\hline \hline Tangkar Dalam & \multicolumn{1}{c}{ Persilangan } & $\begin{array}{c}\text { Bentuk Buah } \\
\text { Membujur }\end{array}$ & $\begin{array}{c}\text { Bentuk yang } \\
\text { Berubah } \\
(-----\%----)\end{array}$ \\
\hline Ranti & Ranti x Indigo Rose & Flattened & 0 \\
Grape & Grape x Ranti & Circular & 66,67 \\
& Grape xRed Pear & & 66,67 \\
Red Pear & Grape x Indigo Rose & Pyriform & 58,88 \\
& Red Pear x Grape & & 42,86 \\
& Red Pear x Ranti & & 40,00 \\
Indigo Rose & Red Pear x Indigo Rose & Oblate & 100,00 \\
& Indigo Rose x Grape & & 66,67 \\
& Indigo Rose x Ranti & & 50,00 \\
& Indigo Rode x Read Pear & 69,23 \\
\hline
\end{tabular}

Keterangan : Persentase bentuk buah yang berubah dihitung dari persentase perubahan bentuk populasi hasil persilangan dibanding bentuk asal tetua betina 
Pengaruh polen terhadap hasil persilangan pada parameter bentuk buah secara membujur disebut efek metaxenia. Efek metaxenia dapat diamati langsung pada hasil persilangan serta memiliki ekspresi fenotipe yang berbeda pada persilangan. Piotto et al. (2013) menyatakan besarnya efek metaxenia dikendalikan oleh sinyal molekuler berupa hormon dan RNA yang diproduksi oleh tetua jantan. Menurut Nasir (2001) karakter kualitatif merupakan karakter

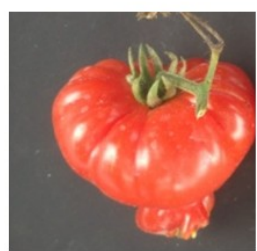

(a)

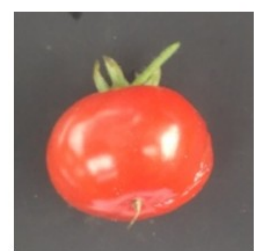

(b)

Ilustrasi 1. Keragaan tomat hasil persilangan dengan var. Ranti sebagai tetua betina. (a) tangkar dalam var. Ranti, (b) Ranti x Indigo Rose

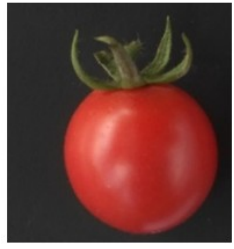

(a)

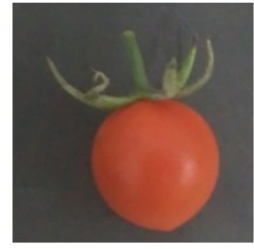

(b)

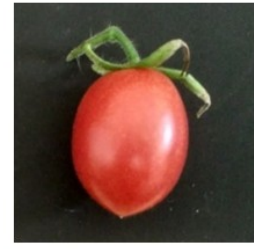

(c)

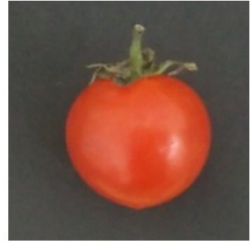

(d)

Ilustrasi 2. Keragaan tomat cherry hasil persilangan dengan var. Grape sebagai tetua betina. (a) tangkar dalam var. Grape, (b) Grape x Ranti, (c) Grape x Red Pear, (d) Grape x Indigo Rose

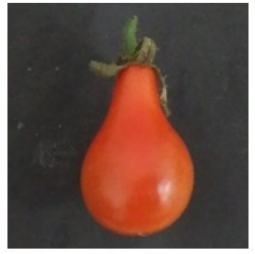

(a)

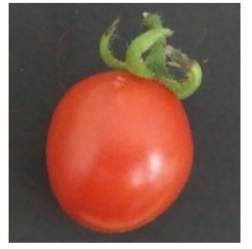

(b)

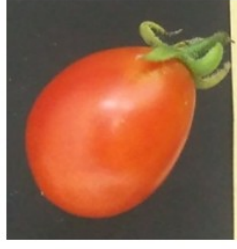

(c)

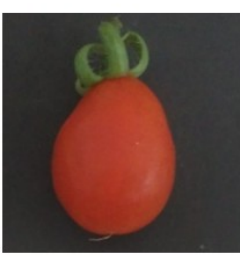

(d)

Ilustrasi 3. Keragaan tomat cherry hasil persilangan dengan varietas Red Pear sebagai tetua betina. (a) tangkar dalam var. Red Pear, (b) Red Pear x Ranti, (c) Red Pear x Grape, (d) Red Pear x Indigo Rose

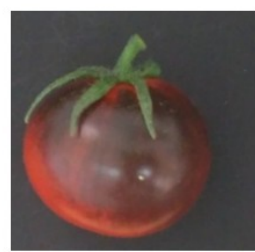

(a)

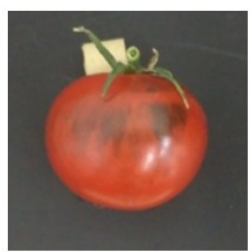

(b)

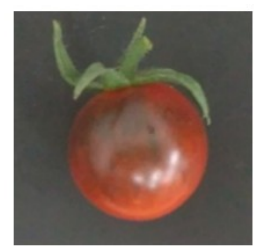

(c)

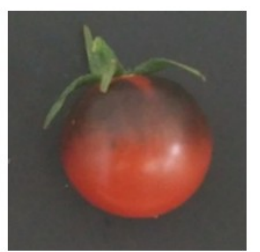

(d)

Ilustrasi 4. Keragaan tomat cherry hasil persilangan dengan varietas Indigo Rose sebagai tetua betina. (a) tangkar dalam var. Indigo Rose, (b) Indigo Rose x Ranti, (c) Indigo Rose x Grape, (d) Indigo Rose $x$ Red Pear 
yang dipengaruhi oleh sedikit gen, sehingga hampir tidak dipengaruhi oleh kondisi lingkungan. Perubahan bentuk buah dapat mempengaruhi ketertarikan konsumen terhadap buah tomat cherry.

\section{KESIMPULAN}

Persilangan tomat Ranti dengan tomat cherry varietas Grape, Red Pear dan Indigo Rose memiliki tingkat kompabilitas persilangan tinggi. Tidak semua kombinasi persilangan mampu membentuk buah. Kombinasi persilangan mampu menciptakan keragaman pada parameter umur panen, jumlah biji dan bentuk buah. Efek xenia maupun metaxenia muncul pada karakter umur panen, jumlah biji dan bentuk buah. Genotipe persilangan Red Pear x Indigo Rose merupakan kandidat genotipe unggul pada karakter umur panen, jumlah biji dan memiliki persentase perubahan bentuk buah membujur yang tinggi.

\section{DAFTAR PUSTAKA}

Aini, M. N. 2008. Pengaruh macam persilangan terhadap hasil dan kemampuan. silang buah naga jenis merah (Hylocereus Polyrhizus). Skripsi. Universitas Sebelas Maret, Solo.

Bullant, C. and Gallais. 1998. Xenia effects in mayze with normal endosperm:importence and stability. J. Crop Sci 39:1517-1525.

Darjanto dan Satifah, S. 1990. Pengetahuan Dasar Biologi Bunga dan Teknik Penyerbukan Silang Buatan. Jakarta: Gramedia.

Denney, J.O. 1992. Xenia includes metaxenia. J. Hort. Science $27: 722-728$.

Frimpong, A. K., M.K. Adjaloo, P.K. Kwangpong, and W. Oduro. 2014. Structure and stability of cocoa flower and their respons to pollinatiom. J. Bot.

Gardner, F.P.,R.B,Pearce dan R.L. Mitchell. 2008. Fisiologi Tanaman Budidaya. Terjemahan. UI Press, Jakarta.

Griffing B. 1956. Concept of general and specific combining ability in relation to diallel crossing system. Aus.Biol Sci 9(4) : 463493.

Hazra .P, H.A. Samsul, D. Sikder, and K.V. Peter. 2007. Breeding tomato (Lycopersicon esculentum Mill.) resistant to high temperature stress. Dalam: Heat tolerance in tomato. Golam F, Prodhan ZH, Nezhadahmadi A, Rahman M. Kuala Lumpur: Universitas Malaya.

Kahriman, F., M. Serment, M. Haslak, and M.S. Kang. 2017. Pollen effect (xenia) for evaluating breeding materials in maize. J. Genetika. 49. 217-234.

Kavitha, P., K. S. Shivashankara, V. K. Rao, A. T. Sadashiva, K. V. Ravishankar and G. J. Sathish. 2014. Genotypic variability for antioxidant and quality parameters among tomato cultivars, hybrids, cherry tomatoes and wild species. J. Science of Food and Agriculture 94: 993-999.

Nasir, M. 2001. Pengantar Pemuliaan Tanaman. Direktorat Jenderal Pendidikan Tinggi, Departemen Pendidikan Nasional, Jakarta.

Olfati, J. A., Z. Sheykhtaher, R. Qamgosar, A. Khasmakhi-Sabet, G. Peyvast, H. Samizadeh, and B. Rabiee. 2010. Xenia and Metaxenia on Cucumber Fruit and Seed Characteristics. Inter. J. Veg. Sci. 16. 243252.

Piotto, F. A., K.D. Batagin-Piotto, M. de Almeida, and G. C. X. Oliveira. 2013. Interspecific xenia and metaxenia in seeds and fruits of tomato. J.Sci. Agric., 70(2), 102-107.

Poespodarsono, S. 1998. Dasar - Dasar Ilmu Pemuliaan Tanaman. IPB Press, Bogor.

Renuka D. M., A. T. Sadashiva, B. T. Kavita, R. C. Vijendrakumar and M. R. Hanumanthiah. 2014. Evaluation of cherry tomato lines (Solanum lycopersicum var. Cerasiforme) for growth, yield and quality traits. J. Plant Archives 14(1):151-154. 
Sa'diyah, N, M. Widiastuti dan Ardian. 2012. Keragaan, keragaman dan heretabilitas karakter agronomi kacang panjang (Vigna Unguiculata) hasil persilangan tiga genotipe. J. Agrotek Tropika 1(1):32-37.

Setyaningsih F. R. 2011. Persilangan dialel pada enam varietas untuk peningkatan hasil kedelai (Glycine max merril). Skripsi.

Setiamihardja, R. 1993. Persilangan antar spesies pada tanaman cabai. J. Zuriat, 4(2): 112-
115.

Syukur, M., S. Sujiprihati, dan R. Yunianti. 2015. Teknik Pemuliaan Tanaman. Penebar Swadaya, Jakarta.

Yunita, T.R., Taryono, dan M.W. Suyadi. 2015. Pengujian sifat kemampuan menyerbuk silang lima klon kakao (Theobroma cacao). Prosiding sem nas masy biodiv indon.

Zipori, I., S. Shuker, A. Dag and E. Tomer. 2007. Guava breeding in Israel. Acta Hortic., 735: $39-47$. 